\title{
The Implementation of Character Education in Physical Education and Health Subject at State Junior High School in Banjarbaru
}

\author{
Herita Warni \\ Lambung Mangkurat University \\ Faculty of Teacher Training and Education \\ Indonesia \\ hwarni@unlam.ac.id
}

\author{
Anjas Rubianti \\ Lambung Mangkurat University \\ Faculty of Teacher Training and Education \\ Indonesia \\ ramadhanarifin49@gmail.com
}

\begin{abstract}
The purpose of this study was to find out how was the implementation of character education in physical education and health subject at the State Junior High School Banjarbaru. The research method qualitative research and the data collection was observation and documentation. The population of this study was the entire Junior High Schools in Banjarbaru while the samples were State School Junior High 13 Banjarbaru, State School Junior High 01 Banjarbaru, and State School Junior High 09 Banjarbaru. The result of this study indicated that the implementation of character education at the State Junior High Schools in Banjarbaru have conducted successfully proven by the students' discipline, diligence, thoroughness, passion, sportsmanship, honesty, responsibility, cooperation, tolerance, confidence, courage, and appreciate the opponent/friend.
\end{abstract}

Keywords-Implementation, Physical Education, Character, Junior High School

\section{INTRODUCTION}

A good physical education and health teachers always try to focus on improving the development of motor skill and behavioral changes. Therefore, the objectives of physical education and health can be achieved. In planning and conducting a teaching and learning process, teachers also should work hard and seriously. Teachers are not only having extensive knowledge but also having a high commitment to achieve the goal of a complete education which corresponds with the national education goal. Physical education and health subject have an important role in the development of learners' character with activity such as game [1].

In fact, many physical education and health teachers plan and conduct the teaching process by paying less attention to the cognitive and effective field. However, these teachers have an educational background as a teacher and some have physical education and health educational background. "In the learning process, discipline value which was seen in the research period was that the teachers and the students obeyed the rule and were on time. Unfortunately, some students still misbehaved. In term of responsibility, the teachers and the students have been responsible for what they were doing, and they were dependable". The teacher gave an insufficient explanation that made the students could not understand what they should do. In addition to that, the teacher only gave a little emphasizing on the good behavior that the students should apply in the teaching and learning process. This might be as the result of the insufficient time allotment. The teacher only emphasized more on the psychomotor field. This leads to a conclusion that the teachers had low ability in planning the lesson and taught without any preparation. The teachers were also considered to teach with traditional style that resulted in students' low motivation in following the lesson. This fact also resulted in the students' misbehavior such as being absent from classes, pretending to be sick, and disobeying the teachers' order in finishing some assignments. This is opposite of the school goal that is to help the students to behave well. "Formal education age ranges from 7 to 12 years old which is the golden age where the students can respond or copy good behavior from what they see and learn. This is why the correct sportive character internalization will be a great base to make the students have good behavior when they grow up" [3]. "Through physical education, the growth of students' intellectual, social and emotional develops by the motoric activity done by the students. With this education, every responsible individual will do their best efforts in optimizing the character and discipline development for the students" [4]. Character-based education is considered as the solution in overcoming the misbehaving of students that lead them away from the national education goal. Even though the characterbased education has existed since long time ago, researchers still wonder whether it has been applied well in the learning process and whether the lesson planning has been conducted well in the real life, especially in Banjarbaru as the education city.

\section{METHODS}

This research was a qualitative research. According to Bogdan and Biklen, qualitatively refers to the term "umbrella", which means a strategy of research with some specific characteristics [5]. This type of research is also called "field research", and often applied by anthropologists and sociologists as their research method. The data was collected by documentation and observation techniques.

\section{RESULTS AND DISCUSSION}

Based on the observation of the first two teachers, it was found that the classes were quite calm and the students were 
obedient. Affective indicators created by the teachers in their lesson plan based on the basic competence in Kurikulum Tingkat Satuan Pendidikan (KTSP) were cooperation, tolerance, self-confidence, bravery, sportiveness, and sharing. In the implementation, the teachers taught self-confidence (this was realized by teachers by giving motivation in warming up stage such as saying "I asked you to gain the spirit..." (08:06/09.90). when the students looked confused, the teachers say, "Try it first, try it..." (08: 44/ 09'91). When they had done the warming up the stage, the teachers gave a compliment to the winners by saying "Give applause to the winners..." (11: 54/09'91). The teachers also gave punishment to the looser according to the deal they made in the beginning such as singing, and the teachers also sing along. (21: 47/09'91).

Based on the observation in teacher 3 class, the class was also quiet and calm. Even though there were disobedient students within the class, the teacher could handle them well. The effective indicators created by the teacher in the lesson plan was not in accordance with KTSP which required the students to be discipline, spirit, sportiveness, self-confidence, and honesty. In the lesson plan, the effective indicator to achieve was teamwork. In the implementation, the teacher taught discipline (this was realized in the warming up stage. The students were chaotic. They tended to move while playing around. Therefore, the teacher warned them by saying "Follow me! I have warned you twice..." (09: 42/ 10'101), "..Come on, do not focus on shoes only.."(11: 40/ 10'102), and a mean warning "...one more disobeying, I will slap you in the face..."(10: 02/ 10'102). In the thigh lifting activity, some students were warned several times that made the teacher said, "if you are not interested in following this activity, please stay out..”(15: 00/ 10’102)) Spirit and self-confidence were also taught (in the motivation stage, the teacher said, "this clear morning and handsome face of mine..'(03: 04/ 10'103), and your class I great, that is why your class is being observed. It means all of you are good looking" (06: 26/ 10'104)).

Based on the observation of teacher 4 , the class was quite controllable. There were some disobedient students, however, this condition was overcome well by the teacher. The effective indicator created by the teacher in the lesson plan was in accordance with the basic competence of KTSP, such as cooperation, tolerance, self-confidence, bravery, sportiveness, and sharing. The teacher also added the point of keen, discipline, and careful in the lesson plan effective indicator. In the implementation, the teacher did not focus on the effective goal (this was because the class was having final examination).

Based on the observation of teacher 5 , the class condition was like teacher 5's. The effective indicator created by the teacher in the lesson plan was in accordance with the basic competence in KTSP, such as cooperation, tolerance, selfconfidence, and bravery. However, the teacher left the sportiveness and sharing points. He added discipline, keenness, responsibility, and carefulness in his lesson plan. In the implementation, the teacher did not apply the affective goals written in the lesson plan.

Based on the observation of teacher 6 , the class was noisy because the students were disobedient and tended to be disrespectful. The effective indicators such as cooperation, tolerance, self-confidence, bravery, sportiveness, and sharing were not written in the lesson plan. In the implementation, the teacher also left these affective goals as well.

Based on the observation of teacher 7 , the class was quite calm, and the students were obedient. The effective indicators such as discipline and responsibility were written by the teachers in their lesson plan. He also added cooperation, self-confidence, and bravery in his lesson plan. In the implementation, the teacher focused on the cognitive value instead of effective value.

\section{Findings}

The research findings are as follow:

TABLE I. Findings AT STATE SCHOOL JUNIOR High 13 BANJARBARU

\begin{tabular}{|l|l|l|l|l|}
\hline Teacher's Name & \multicolumn{1}{|c|}{$\begin{array}{c}\text { Basic Competence } \\
\text { (KTSP) }\end{array}$} & Affective Indicator (RPP) & \multicolumn{1}{|c|}{ Implementation } \\
\hline $\begin{array}{l}\text { AS, } \\
\text { S.Pd }\end{array}$ & $\begin{array}{l}\text { Cooperation } \\
\text { Tolerance } \\
\text { Problem solving } \\
\text { Respecting others } \\
\text { Bravery }\end{array}$ & $\begin{array}{l}\text { Cooperation } \\
\text { Tolerance } \\
\text { Problem solving } \\
\text { Respecting others } \\
\text { Bravery }\end{array}$ & $\begin{array}{l}\text { Not implemented } \\
\text { (no emphasizing on } \\
\text { affective indicators) }\end{array}$ & $\begin{array}{l}\text { Affective indicators created by the teacher } \\
\text { was involving cooperation, tolerance, and } \\
\text { bravery from basic competence (KTSP). He } \\
\text { also added responsibility and keenness in } \\
\text { the lesson plan. He did not focus on } \\
\text { effective values he mentioned in the lesson } \\
\text { plan. }\end{array}$ \\
\end{tabular}


TABLE II. Findings At State SchOol Junior High 09 BANJARBARU

\begin{tabular}{|c|c|c|c|c|}
\hline $\begin{array}{c}\text { Teacher's } \\
\text { Initial Name }\end{array}$ & $\begin{array}{c}\text { Basic Competence } \\
\text { (KTSP) }\end{array}$ & Affective Indicator (RPP) & Implementation & Information \\
\hline $\begin{array}{l}\text { HS, } \\
\text { S. Pd }\end{array}$ & $\begin{array}{l}\text { Cooperation } \\
\text { Tolerance } \\
\text { Self-confidence } \\
\text { Bravery } \\
\text { Sportiveness } \\
\text { Sharing }\end{array}$ & $\begin{array}{l}\text { Cooperation } \\
\text { Tolerance } \\
\text { Self-confidence } \\
\text { Bravery } \\
\text { Sportiveness } \\
\text { Sharing }\end{array}$ & $\begin{array}{l}\text { Self-confidence and } \\
\text { sportiveness }\end{array}$ & $\begin{array}{l}\text { The effective indicators written in lesson } \\
\text { plan was in accordance with basic } \\
\text { competence in KTSP. In the } \\
\text { implementation, he focused on self- } \\
\text { confidence and sportiveness. }\end{array}$ \\
\hline MM, S. Pd & $\begin{array}{l}\text { Discipline } \\
\text { Spirit } \\
\text { Sportiveness } \\
\text { Self-confidence } \\
\text { Honesty }\end{array}$ & $\begin{array}{l}\text { Cooperation } \\
\text { Tolerance } \\
\text { Self-confidence } \\
\text { Bravery } \\
\text { Sportiveness }\end{array}$ & $\begin{array}{l}\text { Discipline, spirit, and self- } \\
\text { confidence. }\end{array}$ & $\begin{array}{l}\text { Discipline, spirit, and self-esteem have been } \\
\text { emphasized (implemented) by the teacher, } \\
\text { but not because it was planned in lesson } \\
\text { plan because the indicators were not in } \\
\text { accordance with KTSP. }\end{array}$ \\
\hline $\mathrm{S}, \mathrm{S} . \mathrm{Pd}$ & $\begin{array}{l}\text { Cooperation } \\
\text { Tolerance } \\
\text { Self-confidence } \\
\text { Bravery } \\
\text { Sportiveness } \\
\text { Sharing }\end{array}$ & $\begin{array}{l}\text { Sharing } \\
\text { Discipline } \\
\text { Keenness } \\
\text { Carefulness }\end{array}$ & $\begin{array}{l}\text { Not implemented (No } \\
\text { emphasizing on effective } \\
\text { values) }\end{array}$ & $\begin{array}{l}\text { The effective indicators made by the } \\
\text { teacher in form of lesson plan were in } \\
\text { accordance with basic competence in } \\
\text { KTSP. He also added discipline, keenness, } \\
\text { and carefulness in his lesson plan. In the } \\
\text { implementation, he did not implement the } \\
\text { effective values. }\end{array}$ \\
\hline
\end{tabular}

TABLE III. Findings At State School Junior High01 BanJARBARU

\begin{tabular}{|c|c|c|c|c|}
\hline $\begin{array}{c}\text { Teacher's } \\
\text { Initial Name }\end{array}$ & $\begin{array}{c}\text { Basic Competence } \\
\text { (KTSP) }\end{array}$ & Affective Indicator (RPP) & Implementation & Information \\
\hline $\begin{array}{l}\text { BR, } \\
\text { S. Pd }\end{array}$ & $\begin{array}{l}\text { Tolerance } \\
\text { Self-confidence } \\
\text { Bravery } \\
\text { Sportiveness } \\
\text { Sharing }\end{array}$ & $\begin{array}{l}\text { Cooperation } \\
\text { Tolerance } \\
\text { Self-confidence } \\
\text { Bravery } \\
\text { Discipline } \\
\text { Keenness } \\
\text { Responsibility } \\
\text { carefulness }\end{array}$ & $\begin{array}{l}\text { Not implemented (No } \\
\text { emphasizing on effective } \\
\text { values) }\end{array}$ & $\begin{array}{l}\text { The effective indicator written by a } \\
\text { teacher in his lesson plan was in } \\
\text { accordance with KTSP. He also added } \\
\text { discipline, keenness, responsibility, and } \\
\text { carefulness in the effective indicator of the } \\
\text { lesson plan. In the implementation, no } \\
\text { emphasis found. }\end{array}$ \\
\hline $\begin{array}{l}\text { AL, } \\
\text { S. Pd }\end{array}$ & $\begin{array}{l}\text { Cooperation } \\
\text { Tolerance } \\
\text { Self-confidence } \\
\text { Bravery }\end{array}$ & $\begin{array}{l}\text { Cooperation } \\
\text { Tolerance } \\
\text { Self-confidence } \\
\text { Bravery }\end{array}$ & $\begin{array}{l}\text { Not implemented (No } \\
\text { emphasizing on effective } \\
\text { values) }\end{array}$ & $\begin{array}{l}\text { The effective indicator written by a } \\
\text { teacher in his lesson plan was in } \\
\text { accordance with KTSP. In the } \\
\text { implementation, no emphasis found. }\end{array}$ \\
\hline TH, S. Pd & $\begin{array}{l}\text { Sportiveness } \\
\text { Sharing } \\
\text { Discipline } \\
\text { Responsibility }\end{array}$ & $\begin{array}{l}\text { Sportiveness } \\
\text { Sharing } \\
\text { Discipline } \\
\text { Responsibility } \\
\text { Cooperation } \\
\text { Self-confidence } \\
\text { Bravery }\end{array}$ & $\begin{array}{l}\text { Not implemented (No } \\
\text { emphasizing on effective } \\
\text { values) }\end{array}$ & $\begin{array}{l}\text { The teacher also added cooperation, self- } \\
\text { confidence, and bravery in his lesson plan. } \\
\text { In the implementation, no emphasis found. }\end{array}$ \\
\hline
\end{tabular}

The data showing effective values in the lesson plan above shows that the effective indicators created by the teachers are in line with government's goal as mentioned in the basic competence of KTSP. In addition to that, the values to achieve were the values of discipline, keenness, carefulness, spirit, sportiveness, honesty, responsibility, cooperation, tolerance, self-confidence, bravery, and sharing.

According to the data above, we can see that 2 out of 7 teachers $(28.5 \%)$ taught self-confidence value, 1 out of 7 teachers $(14.28 \%)$ taught discipline value, 1 out of 7 teachers (14.28\%) taught spirit value, 1 out of 7 teachers $(14.28 \%)$ taught sportiveness or respect, and none of the teachers taught the other values, even though they were written in their lesson plans.

Basically, this study was aimed to figure out the implementation of character-based education through physical education subject on the junior high schools in Banjarbaru. The study was conducted through some steps. We began with making the proposal, conducting a seminar, revising the proposal, completing the permission, and gathering the data. The data gathering did not run smoothly because there were some obstacles such as holiday, bad weather, and some others. The steps of data gathering were collecting the lesson plans which will be used by the teachers, recording the teaching and 
learning processes, designing observation form, observing the implementation of the plans in the teachers' lesson plans related to the affective domain.

Based on the observation of teacher 1, the learning process ran quite smoothly and there was not any significance misbehavior of students. The students tended to be obedient. The teacher included the values of tolerance, bravery, and cooperation of the basic competence in KTSP into the effective indicators in his lesson plan, and excluded the point of problem-solving and respect. However, in the effective indicators, he included responsibility and keenness. In fact, he did not implement the effective values as planned. He should not have left the points of problem solving and respect in the learning process. "One character is related to the other ones as a unity. They combine three aspects such as moral knowledge, moral value, and moral action at once" [6]. Early development of character is very important since it will affect the students' life in the future as has been stated that "qualified character should be formed and taught early because early age is the golden age of developing one's character" [7]. Failure in teaching character in one's early age will result in bad personality in the future.

Based on the observation on the teacher 2, it was found that the classes were quite calm and the students were obedient. Affective indicators created by the teachers in their lesson plan based on the basic competence in KTSP were cooperation, tolerance, self-confidence, bravery, sportiveness, and sharing. In the implementation, the teachers taught self-confidence (this was realized by teachers by giving motivation in warming up stage such as saying "I asked you to gain the spirit..." (08:06/09.90). when the students looked confused, the teachers say, "Try it first, try it..." (08: 44/ 09'91). When they had done the warming up the stage, the teachers gave a compliment to the winners by saying "Give applause to the winners..." (11: 54/09'91). The teachers also gave punishment to the looser according to the deal they made in the beginning such as singing, and the teachers also sing along. (21: 47/ 09'91). In this case, the teacher has fulfilled one of the character principal, "Education process is conducted by the students actively and happily. The learning process is conducted by growing the happy feeling and avoiding to indoctrinate" [8]. He has also fulfilled the character development strategies such as being a good example by being disciplined, punctual, democratic by involving students in creating game rules, responsible, honest, consequent, and others" [8].

Based on the observation in teacher 3 class, the class was also quiet and calm. Even though there were disobedient students within the class, the teacher could handle them well. The effective indicators created by the teacher in the lesson plan was not in accordance with KTSP which required the students to be discipline, spirit, sportiveness, self-confidence, and honesty. In the lesson plan, the effective indicator to achieve was teamwork. In the implementation, the teacher taught discipline (this was realized in the warming up stage. The students were chaotic. They tended to move while playing around. Therefore, the teacher warned them by saying "Follow me! I have warned you twice..." (09: 42/ 10'101), “..Come on, do not focus on shoes only...'(11: 40/ 10'102), and a mean warning "...one more disobeying, I will slap you in the face..."(10: 02/ 10'102). In the thigh lifting activity, some students were warned several times that made the teacher said, "if you are not interested in following this activity, please stay out.."(15: 00/ 10’102)) Spirit and self-confidence were also taught (in the motivation stage, the teacher said, "this clear morning and handsome face of mine.."(03: 04/ 10'103), and your class I great, that is why your class is being observed. It means all of you are good looking" (06: 26/ 10'104)). Even though sometimes the teacher warned them a little mean, it was because he tried to teach good character to the students. In the sports world, discipline is one of the most important characters to have. Basically, discipline will automatically appear when a student feels that he is responsible for what he is doing. "Any action requires knowledge of why it has to be done. If one has achieved the knowledge, he will love it and it leads to a good preparation to accomplish the action" [5].

Based on the observation of teacher 4, the class was quite controllable. There were some disobedient students, however, this condition was overcome well by the teacher. The effective indicator created by the teacher in the lesson plan was in accordance with the basic competence of KTSP, such as cooperation, tolerance, self-confidence, bravery, sportiveness, and sharing. The teacher also added the point of keen, discipline, and careful in the lesson plan effective indicator. In the implementation, the teacher did not focus on the effective goal (this was because the class was having final examination).

Based on the observation of teacher 5 , the class condition was like teacher 5's. The effective indicator created by the teacher in the lesson plan was in accordance with the basic competence in KTSP, such as cooperation, tolerance, selfconfidence, and bravery. However, the teacher left the sportiveness and sharing points. He added discipline, keenness, responsibility, and carefulness in his lesson plan. In the implementation, the teacher did not apply the affective goals written in the lesson plan. A character like a discipline is supposed to be taught in the teaching and learning process. "Discipline is one of the three values of basic character development. The two others are being honest and not being selfish" [5]. In fact, he had tried to teach honesty to the students, even though the teaching was not in a simple sentence that could be understood easily. Teaching honesty to the students at their early age is very important, and as has been stated that "honesty is necessary at any time and any place. Honesty is the basic material of the basic character" [5]. However, being honest along with being lazy will only lead someone nowhere as well. It means that honesty should come along with the other good behaviors.

Based on the observation of teacher 6 , the class was noisy because the students were disobedient and tended to be disrespectful. The effective indicators such as cooperation, tolerance, self-confidence, bravery, sportiveness, and sharing were not written in the lesson plan. In the implementation, the teacher also left these affective goals as well. It should have been written and implemented as well. If they are not done, it means the character teaching to the students as the hope for future has been missing. Teaching is not only meant to improve psychomotor aspect, but also an effective aspect. Human is a complete being, who has cognitive, psychomotor, and affective skills. 
Based on the observation of teacher 7 , the class was quite calm, and the students were obedient. The effective indicators such as discipline and responsibility were written by the teacher in this lesson plan. He also added cooperation, selfconfidence, and bravery in his lesson plan. In the implementation, the teacher focused on the cognitive value instead of effective value. Basically, discipline will automatically appear when a student feels that he is responsible for what he is doing. Any action requires knowledge of why it should be done. If one has achieved the knowledge, he will love it and it leads to a good preparation to accomplish the action.in this case, the teacher should teach the students with simple language.

According to the findings above, it was found that most of the teachers did not explain the indicators to achieve. They tended to communicate non-verbally instead. In fact, communication is the most important thing in human's daily life. In real life teaching, there are some possibilities of the effect that may occur as result of the teachers' communication or explanation such as a) the students understand and are able to implement it in their daily life. This will occur if the teachers can deliver the lesson well, therefore the students can understand them well. b) the students understand but they do not implement it in their daily life. This might occur if the teachers cannot elaborate the material well. The students may understand the instruction, but they cannot see the true intention behind it. c) the students do not understand and cannot implement the teaching in their daily life. This may happen if the teachers cannot elaborate the teaching well and result in misunderstanding because the students are confused about the instruction and intention of the teachers.

There are some complementary studies related to the relation between character and physical education. "There is a significant effect of physical education toward students' character and physical improvement" [9]. "There is a significant improvement in the frequency of achievements achieved as result of the implementation of character values in physical education subject" [10]. There are many approaches to physical education subject to achieve good character, "The strategies to develop character through sports" [11]. Then, "In order to make the approaches in physical education can be applied in formal education, there are some important modifications in the physical education games. Therefore, the game can be used to form the character of the students" [12]. The other study leads to finding, "The game which is conducted well will improve the students' physical, social, and psychological development, therefore the activities such as games are functioned to develop the physical, social, and psychological aspects proportionally. This will occur continuously in a long period of time that will form a constant behavior and a character that is acknowledged by others" [13]. This is why teachers should be able to implement the indicators goal and be able to communicate well to make the students understand the lessons being taught.

\section{CONCLUSION}

Based on the study, it was found that the values that the teachers planned to achieve were discipline, keenness, carefulness, spirit, sportiveness, honesty, responsibility, cooperation, tolerance, self-confidence, bravery, and respect. In fact, there were only some values such as discipline, selfconfidence, spirit, and sportiveness achieved in the process. This fact was proven by seeing the interaction between teachers and students. According to this finding, it is concluded that the teachers could create good lesson plans based on KTSP. However, the implementation of the lesson plans did not run smoothly as planned since the effective indicators were not met. The incomplete communication made the students could not understand the purpose of the learning itself.

\section{ACKNOWLEDGEMENT}

We would like to be grateful to the Dean of Teacher Training and Education Faculty, Lambung Mangkurat University, who has supported us in form of funding, therefore we could join this international seminar. We also would like to thank the committees who have accepted our paper to be presented.

\section{REFERENCES}

[1] Paiman. "Kontribusi Pendidikan Jasmani dalam Membentuk Karakter Peserta Didik." Jurnal Pendidikan Jasmani Dan Olahraga Vol 9. N0. 2 Tahun 2013

[2] Alfian Budi, Prasetya. Penerapan Pendidikan Karakter Nilai Disiplin dan Nilai Tanggung Jawab Dalam Mata Pelajaran Pendidikan Jasmani, Olahraga, dan Kesehatan (PJOK) Di Kelas I dan IV SD Negeri Percobaan 3. Diss. Pgsd, 2015.

[3] Arifin, Syamsul. Internalisasi Nilai-Nilai Sportifitas Melalui Pembelajaran Pendidikan Jasmani Di Sekolah Dasar. Intergitas Jurnal Penelitian Pendidikan dan Karakter. Vol 2. No 1 86, 2013.

[4] Rismayanthi, Cerika. "Optimalisasi Pembentukan Karakter dan Kedisiplinansiswa Sekolah Dasar Melalui Pendidikan JasmaniOlahraga dan Kesehatan.” Jurnal Pendidikan Jasmani Indonesia Vol 8. No. 1, 2011.

[5] Bogdan, R \& Biklen, S.K 1982. Qualitative Research For Education: An Introduction to The Theory and methods. America: Allyn and Baco.

[6] Saptono. Dimensi-Dimensi Pendidikan Karakter Wawasan, Strategi, Dan Langkah Praktis. Jakarta: Esensi Erlangga Group,2011.

[7] Ratna, Megawangi. Pendidikan Karakter Solusi Yang Tepat Untuk Membangun Bangsa. Start Energy (Kakap) Ltd: Jakarta.2004.

[8] Kementerian Pendidikan Nasional. Panduan Pendidikan Karakter di Sekolah Menengah Pertama. Jakarta: Direktorat Jenderal Manajemen Pendidikan Dasar dan Menengah Direktorat Pembinaan Sekolah Menengah Pertama. 2011.

[9] Bafirman, Relationships of Character and Physical Fitness Quality through 'Penjasorkes'Learning to Students of Elementary School. International Journal of Humanities and Social Science, USA. Vol. 6 No. 11. September 2014.

[10] Suherman, A., K. Sultoni, and H. Ilmawati. "Character-Based Physical Education Model" IOP Conference Series: Materials Science and Engineering. Vol. 180. No. 1. IOP Publishing, 2017.

[11] Winarni, Sri. "Pengembangan Karakter dalam Olahraga dan Pendidikan Jasmani." Jurnal Cakrawala Pendidikan 2, 2011.

[12] Basuki, Sunarno. "Pembentukan Karakter Melalui Modifikasi Permainan Dalam Pembelajaran Pendidikan Jasmani.” Jurnal Multilateral 15.2 (2016): 188-196.

[13] Utama, Am Bandi. "Pembentukan Karakter Anak Melalui Aktivitas Bermaindalam Pendidikan Jasmani.” Jurnal Pendidikan Jasmani Indonesia 8.1, 2011. 